\title{
ASAS PSIKOLOGI DAN IMPLIKASINYA DALAM PENDIDIKAN ISLAM PERSPEKTIF HASAN LANGGULUNG
}

\author{
Suminto \\ IAIN Tulungagung \\ e-mail: kangminto990@gmail.com
}

Diterima: 09 Desember 2019 | Direvisi: 24 Mei 2020| Disetujui: 25 Mei 2020

(C) 2018 Program Studi Pendidikan Agama Islam Fakultas Agama Islam Universitas Islam Malang

\begin{abstract}
The psychological principle of Islamic education becomes very important in its own, considering it can be understood as the truth that is a foothold or basic thinking, both in the planning, implementation, or evaluation of education based on the theories of psychology. In addition, understanding the education in it also contains principles as a place and an upright footing, upright in matter, upright in interaction, upright in innovation, or upright in dreams. The type of research used is library research. The analysis of content or content analysis is used as a method of analysis in this study. The results of this study contained the basic concept of psychological in Islamic education according to Hasan Langgulung and the implications of the basic psychological concept in the education of Islamic agam. Therefore, in the process of education should pay attention to the development of the soul, as well as the physical growth of the students by referring to the basis, objectives, curriculum, materials, and evaluation that brings human function as ' abid and the fil decorated with righteous charity.
\end{abstract}

Keywords: Principles Of Psychological, Islamic Education, Hasan Langgulung

\begin{abstract}
Abstrak
Asas psikologis dalam pendidikan Islam menjadi sangat penting keberadannya, mengingat dapat difahami sebagai kebenaran yang menjadi pijakan atau dasar berpikir, baik pada tahap perencanaan, pelaksanaan, maupun evaluasi pendidikan yang berdasarkan atas teori- teori dari psikologi. Selain itu, memahami pendidikan di dalamnya juga terdapat asas-asas sebagai tempat dan pijakan yang tegak, tegak dalam materi, tegak dalam interaksi, tegak dalam inovasi, atau tegak dalam cita-citanya. Jenis penelitian yang digunakan adalah penelitian kepustakaan atau library research. Adapun analisis isi atau content analysis digunakan sebagai metode analisis dalam penelitian ini. Hasil penelitian ini memuat tentang konsep asas psikologis dalam pendidikan Islam menurut Hasan Langgulung dan implikasi dari konsep asas psikologis dalam pendidikan agam Islam. Oleh karenanya, dalam proses pendidikan harus memperhatikan perkembangan jiwa, maupun pertumbuhan raga peserta didik dengan mengacu pada dasar, tujuan, kurikulum, materi, serta evaluasi yang
\end{abstract}


membawa fungsi manusia sebagai 'abid dan khalifatullah yang dihiasi dengan amal saleh.

Kata Kunci: Asas Psikologis, Pendidikan Islam, Hasan Langgulung

\section{Pendahuluan}

Fenomena yang ada di sekitar manusia tidak begitu saja mampu untuk difahaminya. Karena manusia lahir di dunia ini belum mempunyai pengetahuan apapun. Oleh karena itu manusia membutuhkan proses pengarahan agar mampu memahami fenomena yang ada di sekitarnya, yaitu dengan sebuah usaha yang dinamakan pendidikan.

Pendidikan berperan sebagai suatu keniscayaan di dalam kehidupan manusia agar bahagia dan selamat di dunia dan akhirat. Pendidikan sangat berpengaruh dalam kehidupan, di antaranya adalah ekonomi, sains dan teknologi dapat berkembang, kemiskinan dapat dikurangi, serta kualitas peradaban manusia dapat ditingkatkan.

Pendidikan sangat menentukan maju mundurnya peradaban suatu bangsa. Negara yang pendidikannya rendah bisa dikatakan bangsa tersebut ketinggalan zaman. Bahkan manusia yang hidup tanpa pendidikan dapat dipastikan sama seperti generasi manusia masa lampau.

Pendidikan dalam pandangan klasik pada umumnya dioperasikan melalui tiga fungsi utamanya, yaitu Pertama, melatih para generasi muda agar di dalam masyarakat bisa memegang berbagai peranan tertentu sebagai generasi penerus. Kedua, memindahkan pengetahuan (transfer of knowledge) agar selaras dengan peran yang dicita-citakan. Ketiga, memindahkan nilai-nilai yang dapat mempertahankan dan melestarikan keutuhan dan kesatuan masyarakat. (Langgulung, 1980: 92)

Dengan demikian, yang dimaksud pendidikan adalah usaha yang dilakukan manusia untuk mewariskan nilai yang akan digunakan sebagai pedoman untuk secara bersama menjalani kehidupan serta untuk melestarikan dan mengembangkan peradaban umat manusia. Begitulah pendidikan sangat penting (urgen) sebagai pedoman dalam kehidupan manusia, terlebih pendidikan dalam perspektif Islam. Pendidikan Islam menurut Hasan Langgulung didefinisikan menjadi tiga hal, yaitu meliputi aspek pengembangan potensi, pewarisan budaya, dan gabungan antara potensi dan budaya. (Langgulung: 1991: 361-367)

Manusia merupakan obyek sasaran dalam pendidikan Islam. Dalam perspektif pendidikan Islam, manusia akan dibimbing dan diarahkan menjadi seorang yang mukmin, muslim, muhsin, dan muttaqin. Oleh karena itu, pendidikan menurut Islam berarti membentuk manusia yang senantiasa 
taat akan ajaran Allah dan Rasul-Nya. Dengan demikian, pendidikan Islam dapat menciptakan dan membina manusia menjadi pribadi Muslim.

Menurut Dr. Ahmad Arifi, pendidikan Islam mempunyai peranan kunci bagi kontinuitas Islam itu sendiri dan sangat menentukan dalam pembentukan karakter dan perilaku masyarakat Muslim (Moslem society). (Arifi, 1999: 95) Karena pendidikan Islam dapat mengubah dan memperbaiki tingkah laku manusia, baik sebagai individu maupun bermasyarakat, serta memperbaiki cara berinteraksi dengan lingkungan sekitar. (Suyudi, 2005: 55)

Akan tetapi menurut Abdurrahman Assegaf, saat ini pendidikan Islam sedang mengalami masa kemandekan intelektual (intellectual deadlock). Adapun indikasi yang terjadi di antaranya: pertama, kecepatan pembaharuan dalam pendidikan Islam terkalahkan oleh perubahan sosial dan politik (sospol), serta oleh keberhasilan bidang ilmu pengetahuan dan tehnologi. Kedua, Pendidikan Islam cenderung menggunakan konsep lama dalam prakteknya serta kurangnya inovasi dan kreatifitas dalam pemikirannya. Ketiga, penekanan pembelajaran pendidikan Islam masih lebih mengarah pada model dan pendekatan intelektualisme-verbalistik. Keempat, Pendidikan Islam kurang berorientasi pada pencapaian karakter manusia muslim sebagai khalifah fi al-ard. Sebaliknya lebih mengedepankan pembentukan 'abd (hamba Allah). (Assegaf, 2004: 8-9)

Dunia pendidikan di masa sekarang sedang menghadapi berbagai tantangan yang tidak mudah, sehingga semua pihak perlu terlibat untuk menanganinya. (Nata, 2008: 104) Oleh karena itu, perlu memperhatikan beberapa hal seperti yang disampaikan oleh Prof. Dr. Mastuhu, bahwa untuk mencari paradigma baru dalam pendidikan Islam harus memulainya dengan mempelajari tentang konsep manusia dari sudut pandang Islam, pendapat Islam berkaitan dengan IPTEK dan perkembangannya, kemudian merumuskan sistem atau konsep pendidikan Islam secara utuh dan menyeluruh. (Mastuhu, 1999: 15)

Menjadi suatu hal yang logis untuk memahami bahwa dunia pendidikan sangat penting digunakan guna memecahkan masalah dan memberikan jawaban atas tantangan-tantangan zaman. Kelangsungan kehidupan suatu bangsa akan gagal jika suatu pendidikan gagal dalam mempersiapkan masa depan. (Nata, 2003: 159-160). Oleh karena itu, semua aspek yang ada kaitannya dengan pendidikan seperti hal nya guru, materi pelajaran yang disampaikan, metode yang digunakan, sarana serta prasarana yang tersedia, lingkungan tempat belajar, serta hubungan diantara guru dan 
siswa perlu dilakukan penataan ulang agar sesuai dengan perkembangan zaman.

Terdapat berbagai asas dalam pendidikan menurut Hasan Langgulung. Diantaranya yaitu asas historis, sosial, ekonomi, politik dan administrasi, psikologis, serta filsafat. Di antara asas-asas tersebut, nampaknya asas psikologis yang berperan paling penting dalam pengembangan fitrah manusia, yaitu dalam proses pendidikan yang sesungguhnya. Karena ketika berbicara tentang proses pendidikan, tentunya tidak akan lepas dari masalah tingkah laku, biologis, pertumbuhan serta perkembangan, kematangan, kemampuan serta kecerdasan, minat dan sikap serta aspekaspek lain yang berkaitan dengan kejiwaan manusia.

Menurut Hasan Langgulung dari sekian banyak teori dalam psikologi, tidak ada yang berani mengklaim bahwa dialah yang dapat menerangkan segala bentuk proses belajar tersebut. Hal ini disebabkan bukan saja karena proses belajar yang sangat rumit untuk dijelaskan dengan suatu teori tunggal, tetapi juga karena suasana dan kondisi di mana proses belajar itu berlaku. (Langgulung, 1988: 390) Dengan demikian, penelitian tentang konsep pendidikan Islam dengan pendekatan psikologis sangat perlu dilakukan, agar khazanah keilmuan pendidikan Islam, baik secara teoritik maupun praktik senantiasa berkembang dan tidak stagnan.

Salah satu langkah dalam mengembangkan pendidikan Islam, sebaiknya memperhatikan apa yang disampaikan oleh Wan Daud, yakni menggali berbagai hasil pemikiran yang dikembangkan oleh para tokoh pendidikan. Sehingga akan menghasilkan suatu konsep tentang pendidikan, yang selanjutnya dapat dijadikan sebagai salah satu landasan filosofis pendidikan. (Daud, 1998: 17-19) Oleh karena itu sangat penting melakukan kajian terhadap pemikiran para tokoh pendidikan, terutama tentang upaya untuk melahirkan suatu konsep pendidikan dengan memberikan pemecahan terhadap berbagai persoalan kemanusiaan yang terjadi saat ini.

Melihat urgennya problem pendidikan, maka para tokoh pendidikan selalu berusaha untuk melahirkan berbagai pemikiran yang berkaitan dengan pendidikan. Pemikiran-pemikiran tersebut dapat berupa pemikiran yang sifatnya baru, juga pemikiran yang bersifat pengembangan atau pembaharuan yang lahir dari pemikiran terdahulu. Hal ini bertujuan agar pendidikan dapat berlangsung dengan tepat sasaran, yaitu bermanfaat di dalam kehidupan dan dapat memajukan peradaban yang sudah ada sehingga dapat membawa manusia pada status 'abd dan khalifatullah fi al'ard. 
Berdasarkan pemaparan di atas, Hasan Langgulung dipilih sebagai tokoh yang diangkat pada penelitian ini berdasar pada kriteria ketokohan. Pertama, seseorang yang berhasil di bidang yang digelutinya; kedua, berbagai karya fenomenal telah dihasilkannya; ketiga, memiliki pengaruh di tengah masyarakat; keempat, masyarakat telah mengakui akan ketokohannya. (Furchan dan Maimun, 2005: 12-13) Berkaitan dengan ketokohan Hasan Langgulung di bidang pemikir pendidikan Islam ini, Azyumardi Azra mengungkapkan bahwa Hasan Langgulung merupakan seorang pemikir yang paling menonjol diantara para pengkaji teori kependidikan yang ada di Indonesia. (Azra, 2000: 90)

Oleh karena itu, Penulis memilih Hasan Langgulung yang merupakan tokoh Pemikiran Pendidikan Islam sebagai obyek kajian berdasarkan beberapa alasan, yaitu: pertama, Kemampuan intelektual Hasan Langgulung dalam bidang pendidikan Islam sudah tidak diragukan, terbukti dengan kemampuannya di bidang akademik dan prestasi yang diraihnya, bahkan dengan keberhasilannya sebagai guru besar dibidang pendidikan dari Universitas Kebangsaan Malaysia. Kedua, Hasan Langgulung mempunyai banyak karya- karya yang dihasilkannya, terutama dibidang pendidikan Islam, psikologi, filsafat, dan Islam. Ketiga, Hasan Langgulung merupakan seorang figur yang berintegritas tinggi di dunia pendidikan dalam skala nasional maupun internasional. Keempat, penulis merasa tertarik untuk mengkaji pemikiran Hasan Langgulung disebabkan beliau juga merupakan seorang pemikir kontemporer yang selalu berupaya melakukan islamisasi ilmu pengetahuan yang berfokus di bidang psikologi dan pendidikan. Kelima, pemikiran Langgulung selalu mengikuti kondisi zaman serta mempunyai relevansi dengan perkembangan sains dan teknologi.

Penulis tidak bermaksud mengesampingkan tokoh-tokoh pendidikan Islam lainnya atas pemilihan Hasan Langgulung sebagai objek kajian dalam penelitian ini. Namun lebih dikarenakan karakteristik dan pendekatan pemikiran Hasan Langgulung memiliki daya beda untuk dikaji, terutama berkaitan dengan psikologis sebagai asas dalam pendidikan Islam dan analisa terhadap proses pendidikan dengan pendekatan psikologis. Karena itu dengan pendekatan psikologis, konsepsi tentang manusia sebagai subjek dan objek pendidikan dapat dipelajari dan didalami, baik dari aspek kejiwaan, tingkah laku, perkembangan, pertumbuhan, serta aspek-aspek lain yang bersifat psikologis. Dengan demikian, dapat mempermudah dalam mencapai dan mengaktualisasikan tujuan pendidikan itu sendiri.

\section{Metode}


Jenis penelitian yang digunakan dalam penelitian ini adalah menggunakan kepustakaan (library research). Pengertian library research atau penelitian kepustakaan adalah penelitian yang menggunakan literatur berupa buku, catatan, atau laporan hasil penelitian dari penelitian terdahulu. (Hasan, 2002: 11)

Data diperoleh melalui metode dokumentasi. Yaitu data akan digali dari berbagai informasi atau catatan, transkrip, buku, jurnal serta media cetak lainnya. Metode ini mengandalkan teori-teori yang ada untuk selanjutnya dijelaskan secara lebih jelas dan mendalam. (Soejono, 1999: 14) Sebagai tindak lanjut, Peneliti akan mengidentifikasi wacana dari berbagai buku, makalah atau artikel, majalah, jurnal, web, serta dari berbagai sumber lain yang sesuai dengan penelitian ini. Sehingga penelitian ini menggunakan pengumpulan data berupa penelusuran literatur.

Content analysis (analisis isi) digunakan peneliti untuk menganalisis data. Content analisys merupakan usaha yang dilakukan peneliti untuk melakukan pengumpulan dan penyusunan data yang akan di analisis. (Surahmad, 1990: 139)

\section{Pembahasan}

Secara etimologi asas diyakini sebagai dasar yang dijadikan sebagai tumpuan berpikir atau pendapat. Sehingga apabila digunakan dalam pendidikan, maka asas tersebut merupakan sesuatu yang memberikan dasar atau landasan yang di dalamnya termuat nilai-nilai positif yang kebenarannya diyakini oleh penyelenggara pendidikan. Hal ini bertujuan agar penyelenggaraan pendidikan berjalan sesuai harapan. Sehingga asas pendidikan yang dimaksudkan adalah dasar atau tumpuan berpikir pada tahap perencanaan atau pada tahap pelaksanaan pendidikan.

Istilah psikologi berasal dari dua kata Yunani psycho dan logos yang memiliki arti jiwa dan ilmu. Kemudian dari penjelasan tersebut psikologi merupakan rangkaian kata yang bermakna ilmu jiwa, di mana dalam bahasa Arab disebut 'ilmun nafs, yang juga bermakna ilmu jiwa. Sedangkan menurut Netty Hartati, psikologi merupakan disiplin ilmu yang pusat pembahasannya yaitu manusia dan tingkah lakunya sebagai individu, serta cara interaksinya dengan masyarakat.

Dalam istilah pendidikan, terdapat dua aspek penting yang mendapat perhatian besar psikologi, yaitu aspek mengajar (teaching) dan aspek belajar (learning). Sehingga kedua aspek tersebut mendorong begitu banyak penyelidikan. 
Kajian-kajian dalam psikologi menunjukan bahwa belajar lebih penting dari pada mengajar, karena mengajar hanya salah satu cara memantapkan proses belajar itu. Buktinya banyak orang belajar tanpa diajar, bahkan mereka bisa belajar sendiri atau dengan sebutan autodidak. Maka seharusnya yang menjadi perhatian adalah pada belajar tersebut. Sehingga yang menjadi kajian khusus para ahli psikologi yaitu bagaimanakah proses belajar berlaku pada manusia, yang kemudian muncul satu cabang psikologi yang khusus mengenai belajar yang dinamakan psikologi belajar (psychology of learning). (Langgulung, 1988: 23)

Kedudukan asas-asas pendidikan menurut Hasan Langgulung adalah sebagai tempat pijakan bagaimana dan ke mana suatu pendidikan akan dibangun dan diarahkan. Oleh karena itu, asas pendidikan memiliki kedudukan yang sangat penting dalam menentukan keberhasilan pendidikan. Asas-asas pendidikan tersebut yang Pertama yaitu asas yang membekali pendidik dengan berbagai pengalaman di waktu lalu yang disebut asas historis. Kedua, asas yang memberikan kerangka budaya dalam upaya untuk memilih dan mengembangkannya dinamakan asas sosial. Ketiga, asas yang memberi pandangan terhadap berbagai potensi manusia untuk menyusun keuangan serta tanggungjawab atas anggaran belanjanya merupakan asas ekonomi.

Asas keempat dari asas pendidikan menurut Hasan Langgulung adalah asas yang memberi bingkai ideologi atau aqidah dalam mencapai tujuan yang telah direncanakan adalah asas politik dan administrasi. Kelima yaitu asas yang memberikan informasi tentang kepribadian peserta didik, guru, pencapaian dan penilaian, serta bimbingan disebut asas psikologi. Keenam adalah asas yang memberikan bantuan dalam memilih suatu sistem yang lebih baik, serta mengontrolnya dan memberikan arah kepada semua asasasas lainnya dinamakan asas filsafat. (Langgulung, 1988: 6)

Enam asas pendidikan tersebut menurut Hasan Langgulung merupakan tempat pijakan berdirinya pendidikan Islam ditegakkan untuk selanjutnya dikembangkan sehingga sesuai dengan tujuannya. Sedangkan dalam penelitian ini akan dikaji konsep dan implikasi asas psikologis dalam pendidikan Islam.

\section{Sekilas tentang Hasan Langgulung}

Lahir pada tanggal 16 Oktober 1934 di Rappang Ujung Pandang, Hasan Langgulung merupakan putra daerah provinsi Sulawesi Selatan. Langgulung berasal dari nama ayahnya serta ibunya yang bernama Aminah Tanrasuh. Secara keturunan mereka termasuk dari suku Bugis. Berdasarkan perjalanan hidupnya Hasan Langgulung dikenal sangat gigih dan 
bersemangat dalam menuntut ilmu, baik mulai sejak pendidikan dasar, menengah, bahkan sampai dengan perguruan tinggi. Sehingga tidak mengherankan bila dalam perjalanan prestasi akademisnya kemudian beliau menjadi seorang Profesor dalam bidang pendidikan, yaitu di Universitas Kebangsaan Malaysia (UKM).

Riwayat pendidikan yang ditempuh oleh Hasan Langgulung secara ringkas dapat dilihat pada penjelasan berikut:

a. 1943 - 1949, SD di Rappang, Ujung Pandang

b. 1949 - 1952, Pendidikan menengah pertama dan Sekolah Menengah Islam di Ujung Pandang

c. 1952 - 1955, Sekolah Guru Islam Atas di Ujung Pandang. (Kurniawan dan Mahrus, 2011: 272)

d. 1955 - 1957, B.I. Inggris di Ujung Pandang

e. 1957 - 1962, B.A. dalam Islamic Studies dan Fakultas Dar Al Ulum, Cairo University

f. 1963 - 1964, Diploma of Education (General), Ein Syams University, di Cairo

g. 1963 - 1964, Special Diploma of Education (Mental Hygiene), Ein Shams University, Cairo.

h. 1964, Diploma dalam Sastra Arab Modern dari Institute of Higher Arab Studies, Arab League, Cairo

i. 1967, M.A. dalam Psikologi dan Kesehatan Mental (Mental Hygiene) Ein Syams University, Cairo.

j. 1971 meraih gelar Ph. D. dalam Psikologi. University of Georgia, Amerika Serikat, tahun. (Langgulung, 1986: 409)

Di antara karya-karya Hasan Langgulung sebagai hasil pemikiran maupun terjemahan yang pernah ditulisnya adalah sebagai berikut:

a. Thesis M.A. : Al-Murahiq al-Indonesiy; Ittijahatuh wa Darajatutawafuq Indahu yang diterbitkan oleh Remaja tahun 1967.

b. Disertasi Ph.D. : A Cross-Cultural Study of The Childís Conception of Situational Causality in India, Western Samoa, Mexico, and The United States, yang dimuat dalam Journal of Social Psychology: USA tahun 1973

c. The Development of Causal Thinking of Children in Mexico and The United States, USA: The Journal of Cross-Cultural Studies tahun 1973

d. The Curriculum Reform of General Education in Higher Education in Southeast Asia, tahun 1974

e. The Self; Concept of Indonesian Adolescene, tahun 1975

f. Social Aims and Effect of Higher Education, tahun 1973

g. Beberapa Aspek Pendidikan Ditinjau dari Segi Islam, tahun 1974 
h. Belia, Pendidikan dan Moral, tahun 1977

i. Al-Ghazali dan Ibnu Thufail Vs Rousseau dan Pioget, tahun 1976

j. Pendidikan Islam akan Kemana?, tahun 1977

k. Peranan Ibu-Bapa dalam Pendidikan Keluarga, tahun 1977

l. Falsafah Pendidikan Islam, terjemahan dari karya Omar Mohammad al-Toumy al-Syaibany, tahun 1979

m. Beberapa Pemikiran tentang Pendidikan Islam, tahun 1980

n. Pendidikan dan Peradaban Islam, tahun 1985

o. Manusia dan Pendidikan; Suatu Analisa Psikologi dan Pendidikan, tahun 1986

p. Teori-teori Kesehatan Mental, tahun 1983

q. Kreatifitas dan Pendidikan Islam; Analisis Psikologi dan Pendidikan Islam, tahun 1991

r. Peralihan Paradigma dalam Pendidikan Islam dan Sains Sosial, tahun 2002

s. Asas-asas Pendidikan Islam, tahun 1988.

t. Pendidikan Islam dalam Abad 21, tahun 2003. (Langgulung, 1988: 401)

Berikut beberapa penghargaan dan prestasi yang telah diraih oleh Prof.

Dr. Hasan Langgulung, baik nasional maupun internasional, di antaranya adalah sebagai berikut:

a. Directory of American Psychological Association,

b. Whoís Who in Malaysia,

c. International Whoís Who of Intellectuals,

d. Whoís Who in The World,

e. Directory of International Biography,

f. Directory of Cross-Cultural Research and Researches,

g. Men of Achievement,

h. The International Book of Honor,

i. Directory of American Educational Research Association,

j. The International Register Profiles,

k. Whoís Who in The Commonwealth,

l. Asia Whoís Who of Men and Women of Achievement and Distinction,

m. Community Leaders of The World,

n. Progressive Personalities in Profile, dan beberapa penghargaan lainnya. (Langgulung, 1988: 401)

Demikianlah profil beliau yang merupakan salah seorang pemikir Muslim di Asia Tenggara. Dengan berfokus di bidang pendidikan dan Psikologi, beliau telah banyak menuangkan perhatiannya pada Islamisasi 
Ilmu Pengetahuan. Hasan Langgulung berusaha mencoba untuk memberikan sumbangsihnya dalam mengembangkan pemikiran pendidikan Islam melalui pemikirannya yang dituangkan dalam setiap karya-karyanya. Hal ini dilakukan sebagai langkah nyata serta upaya untuk menyelesaikan berbagai persoalan yang menyelimuti sistem pendidikan Islam pada saat ini. Sehingga Langgulung sangat berharap keutuhan akan tercipta, yaitu dengan terbentuknya sistem pendidikan Islam modern.

Upaya yang dilakukan oleh beliau adalah dengan menggabungkan pemikiran Barat modern dengan pemikiran Islam., Sumbangsih terbesar bagi dunia intelektual pendidikan Islam telah diberikan oleh Hasan Langgulung melalui berbagi karya yang dan kiprahnya di dunia pendidikan. Terkhusus lagi bagi para peneliti pendidikan yang memiliki keinginan untuk mengkaji dan mengembangkan pemikiran pendidikan Islam di Indonesia. Sebagai seorang intelektual pendidikan, kiprahnya tidak akan pernah padam. Beliau akan selalu dikenang sebagai tokoh pemikiran pendidikan Islam melalui karya-karyanya .

\section{Konsep Asas Psikologis dalam Pendidikan Islam}

Konsep asas psikologis dalam pendidikan Islam menurut pemikiran Hasan Langgulung memiliki pengertian bahwa asas psikologis merupakan dasar berpikir pada tahapan perencanaan maupun pelaksanaan pendidikan yang berdasarkan atas teori-teori dari psikologi. Sehingga asas psikologis tersebut berperan sebagai tempat pijakan berdirinya pendidikan Islam untuk selanjutnya dikembangkan sesuai dengan arah dan tujuannya.

Menguraikan tentang asas-asas psikologis pendidikan Islam, Hasan Langgulung memulainya dengan teori-teori proses belajar dalam psikologi. Ketika kita ingin mengetahui tentang bagaimanakah proses belajar, maka seyogyanya juga mengetahui terlebih dahulu tentang teori-teori belajar dalam psikologi. Gagasan Muhibbin tentang teori belajar secara pragmatis dipahami sebagai suatu prinsip umum atau berisikan kumpulan prinsip yang saling berkaitan dan merupakan penguraian dari berbagai fakta serta penemuan yang ada kaitannya dengan peristiwa belajar. (Syah, 2007: 102103)

Konsep asas psikologis dalam pendidikan Islam menurut Hasan Langgulung adalah dengan jalan membangun pendidikan berdasarkan konsep belajar yang lebih menekankan pada proses pemindahan (transmission). Sebagaimana fungsi dari pendidikan adalah untuk memindahkan kebudayaan, keterampilan dan nilai-nilai dari generasi terdahulu kepada generasi muda sebagai upaya untuk memelihara jati diri masyarakat. Oleh karena itu Hasan Langgulung juga menjelaskan proses 
belajar berdasarkan beberapa teori, yaitu teori-teori asosiasi, teori-teori lapangan, proses belajar sosial, proses belajar antar peradaban, dan belajar untuk belajar.

Kerangka umum teori assosiasi ini adalah menekankan pembentukan hubungan antara perangsang-perangsang dan gerak balas yang terkenal dengan teori $\mathrm{S}-\mathrm{R}$, dimana $\mathrm{S}$ melambangkan perangsang (stimulus), sedangkan R melambangkan gerak balas (respon). (Langgulung, 1991: 224) Sedangkan teori lapangan memandang proses belajar sebagai suatu perubahan dalam susunan kognitif, yakni melalui cara yang baru objekobjek dan suasana-suasana mengalami perubahan. Karena itu menurut pandangan ini, pendidik harus memperhitungkan keseluruhan suasana sebagai satu kesatuan, dan bukan sebagai rangkaian dari potonganpotongan yang terpisah. Sedangkan menurut teori belajar sosial, bahwa banyak tingkah laku belajar manusia yang melibatkan tiruan. Dalam berbagai situasi orang menyelesaikan masalah bukan dengan mencobacoba suatu respon sesudah yang lain sehingga sampai dengan diberikannya ganjaran, akan tetapi seseorang melakukan karena melihat sesuatu yang dilakukan oleh orang lain. (Langgulung, 1988: 257)

Selain itu juga dijelaskannya tentang tahapan dalam belajar yang meliputi: pemerolehan pengetahuan, pembentukan konsep, penyelesaian masalah, dan pemikiran kreatif. Sehingga selain proses belajar, yang perlu diperhatikan dalam pendidikan Islam menurut asas psikologis adalah faktor pertumbuhan dan perkembangan kognitif manusia yang meliputi kognitif, psikologis, dan jasmaniah. Di mana dalam hal ini Hasan Langgulung lebih menekankan pada tahapan pertumbuhan dan perkembangan kognitif manusia.

Hasan Langgulung memandang pertumbuhan dan perkembangan kognitif manusia secara menyeluruh sebagaimana Jean Piaget menggambarkannya dalam teori tentang perkembangan kognitif dari lahir sampai dewasa. Keseluruhan tahap-tahap perkembangan kognitif tersebut kemudian oleh Langgulung disimpulkan dalam empat ciri-ciri tahap perkembangan sebagai berikut:

a. Tahap-tahap yang berbeda-beda itu membentuk urutan.

b. Tahap-tahap itu berhirarki, yang semakin lama semakin bertambah canggih dan berintegrasi.

c. Tahap-tahap pencapaiannya berbeda dalam batas-batas tertentu, karena faktor budaya dan lingkungan. 
d. Faktor budaya tidak dapat merubah urutan tahapan perkembangan meskipun bisa mempercepat atau memperlambat perkembangan kognitif. (Langgulung, 1988: 267)

Sedangkan tahap pokok perkembangan intelektual menurut Piaget, sebagaimana dikutip oleh Hasan Langgulung ada empat yaitu:

a. Usia nol sampai dengan dua tahun, merupakan tahap deria-motor;

b. Usia dua sampai dengan tujuh tahun, merupakan tahap pra-operasi;

c. Usia tujuh sampai dengan sebelas tahun, merupakan tahap operasi konkrit;

d. Usia sebelas tahun ke atas merupakan tahap operasi formal, (Langgulung, 1988: 268)

Berkaitan dengan teori perkembangan kognitif, selain dari teori Piaget sebenarnya masih banyak lagi teori lain yang membahasnya. Walaupun diantara teori-teori tersebut berbeda satu sama lain, terutama berkenaan dengan kecerdasan dan berbagai aspek pertumbuhan dan perkembangan, namun juga disepakati bahwa setiap kanak-kanak haruslah ditolong untuk memperoleh pertumbuhan dan perkembangannya secara maksimal melalui rangsangan dan pendidikan atau persekolahan yang sesuai. Lebih lanjut, menurut Langgulung bahwa masa pertumbuhan yang paling penting dalam perkembangan kognitif adalah sebelum anak masuk sekolah dan pada tahun-tahun awal.

Oleh karena itu pada fase kanak-kanak, aspek yang perlu dikembangkan menurut para ahli pendidikan yaitu berbagai aspek intelektual, emosional, sosial, jasmani, pergerakan (motorik), estetik, serta moral. Pada masa taman kanak-kanak, maka fungsi aspek intelektual menurut Sonquist dan Kami sebagaimana yang dikutip Hasan Langgulung adalah mempermudah (facilitate) peralihan dari fase kecerdasan sensori motorik ke fase kecerdasan konseptual serta membangun dasar yang kuat bagi perkembangan selanjutnya. (Langgulung, 1985: 66)

Sedangkan menurut pandangan Islam, sudah sangat jelas bahwa dalam penekanan terhadap signifikansi fungsi akal ( kognitif) dan fungsi indera (sensori) berperan sebagai komponen penting untuk proses belajar. Walaupun tidak dijelaskan secara detail namun isyarat- isyarat tersebut banyak terkandung dalam berbagai kata kunci ayat-ayat al-Qur'an seperti: ya'qilun, yatafakkarun, yubshirun, yasma'un, yang dijadikan bukti betapa pentingnya penggunaan fungsi ranah cipta-karsa manusia dalam proses belajar dan meraih ilmu pengetahuan.

Dalam konsep asas psikologis Hasan Langgulung juga menekankan pada konsep manusia, yang tentunya menurut perspektif Islam, yaitu 
sebagai 'abid dan khalifatullah, dengan potensi dasar yang diberikan sejak lahir yaitu fitrah. Dimana dalam perkembangan psikologis dan ruhaniahnya manusia akan sangat dipengaruhi oleh unsur jiwa, dengan berbagai ciri-ciri dan fase-fase perkembangannya seiring dengan pengaruh lingkungan sekitarnya. Oleh karenanya interaksi roh dan badan menciptakan pola tingkah laku manusia sebagai suatu pribadi yang terpadu. Karena itu proses pendidikan ataupun belajar dalam pendidikan Islam harus memperhatikan dan berdasarkan atas prinsip-prinsip psikologis tersebut.

Konsep yang benar berkaitan dengan manusia yang memiliki landasan kuat dan jelas, tentunya sangat dibutuhkan. Sehingga manusia akan dipandang dan ditempatkan sesuai tempatnya. Oleh karena itu gagasan tentang manusia yang telah diuraikan oleh Langgulung jika dihubungkan dengan permasalahan krisis kemanusiaan saat ini diharapkan mampu menghasilkan alternative jalan keluar untuk memecahkan persoalan dalam pendidikan Islam.

\section{Implikasi Konsep Asas Psikologi dalam Pendidikan Islam}

Pendidikan Islam terdiri dari proses spiritual, akhlak intelektual, dan sosial yang berusaha memberi tuntunan dan nilai bagi manusia, serta berbagai prinsip untuk mempersiapkan kehidupan di dunia dan di akhirat. Oleh karena itu, Hasan Langgulung dalam konsepnya tentang pendidikan Islam menekankan adanya pendidikan seumur hidup. Alasannya karena sebagai seorang khalifah di muka bumi manusia harus mengetahui segala sesuatu yang bisa menjadikannya khalifah yang sempurna (paling tidak mendekati sempurna), sedang ilmu yang ada tidaklah terbatas, sehingga dengan demikian maka manusia dituntut untuk mencari ilmu dalam sepanjang hidupnya.

Pendidikan tersebut memiliki fungsi yaitu sebagai pengembangan potensi (fitrah). Fungsi pendidikan tersebut dapat dilihat dengan menggunakan tiga pendekatan, yaitu fungsi pengembangan potensi, fungsi pewarisan budaya, dan fungsi interaksi antara potensi dan budaya.

a. Fungsi Pengembangan Potensi

Menurut fungsi ini, pendidikan berperan mengembangkan potensi manusia dalam kehidupannya. Potensi tersebut merupakan pemberian Tuhan, sebagaimana firman Allah yang artinya: "Maka apabila aku telah menyempurnakan kejadiannya, dan telah meniupkan kedalamnya ruh (ciptaan)-Ku, Maka tunduklah kamu kepadanya dengan bersujud." (QS. alHijr: 29)

Sedangkan pendidikan Islam sendiri berpangkal pada titik tolak bahwa setiap manusia dilahirkan dengan bakat-bakat dan potensi-potensi yang 
bersih atau fitrah, sehingga sebenarnya anak tersebut dengan bakat yang dimilikinya sudah siap semenjak lahir untuk menjadi baik, tetapi pada perkembangan berikutnya tergantung pada alam sekitar, termasuk ibu bapaknya, teman, institusi pendidikan, atau lainnya yang akan mempengaruhi, yaitu menjadikan dia baik atau rusak.

Jadi pendidikan Islam memandang bahwa kedua faktor, yaitu potensipotensi (fitrah) dan alam sekitar memiliki peran yang sama dalam perkembangan manusia. (Langgulung, 1991: 71) Hal ini sesuai dengan hadits Rasulullah yang mengatakan bahwa "Setiap anak dilahirkan dalam keadaan fitrah, maka kedua orang tuanyalah yang menjadikan anak tersebut beragama Yahudi, Nasrani atau Majusi." (Bukhari, 1992: 585)

Manusia harus mengembangkan potensi yang dikaruniakan oleh Tuhan. Sedangkan pengembangan potensi manusia harus sesuai dengan petunjuk dari Tuhan yang dikenal dengan istilah 'ibadat. Berbagai potensi dasar sesungguhnya telah dimiliki oleh manusia yang kemudian akan dikembangkan dalam kehidupanya, atau dalam Islam juga disebut dengan istilah fitrah. Sehingga proses menumbuhkan dan mengembangkan berbagai potensi yang dimiliki manusia salah satunya melalui pendidikan.

Potensi yang tidak ada batas perkembangannya ini perlu dibimbing, dalam segi inilah bahwa pendidikan Islam merupakan sebuah proses menemukan dan mengembangkan berbagai potensi yang tersembunyi dan tidak terkira banyaknya. Sehingga implikasinya dalam pendidikan sangat luas, yaitu melibatkan dasar, sistem, tujuan, kurikulum, dalam pendidikan Islam.

b. Fungsi Pewarisan Budaya

Fungsi dari Pendidikan Islam berikutnya adalah mewariskan ajaranajaran Islam ke dalam kehidupan individu dan masyarakat dengan berbagai nilai peradaban yang akan selalu tumbuh dan berkembang sebagai nilai yang menjadi landasan di dalam kehidupan. Oleh karenanya yang perlu diperhatikan dalam pendidikan Islam yaitu bagaimana memindahkan unsur-unsur pokok peradaban tersebut dari satu generasi ke generasi selanjutnya sehingga identitas ummah senantiasa terjaga dan eksis sepanjang masa.

c. Fungsi Interaksi Antara Potensi dan Budaya

Fungsi ini menunjukkan bahwa setiap individu memiliki potensi dasar sebagai potensi yang melengkapinya dalam menegakkan peradaban dan kebudayaan Islam.

Menurut Hasan Langgulung konsep fitrah dan pendidikan Islam yang berfungsi sebagai interaksi antara potensi dan budaya sangat berkaitan. 
Fitrah sendiri memiliki du fungsi sudut pandang yaitu fitrah sebagai potensi yang melengkapi manusia sejak lahir dan fitrah sebagai din yang menjadi penegak peradaban Islam. Selain itu pendidikan meliputi kehidupan manusia secara utuh, maksudnya tidak selalu memperhatikan segi akidah, namun ibadah serta akhlak juga diperhatikan. (Langgulung, 1985: 3)

Pada dasarnya tujuan pendidikan Islam tidak terlepas dengan hakikat penciptaan manusia sebagai khalifah Allah di muka bumi dan juga sebagai 'abd Allah. Di mana tujuan pendidikan Islam tersebut dijabarkan menjadi tiga, yaitu tujuan tertinggi, umum serta khusus. Di mana tujuan tertinggi (ultimate aim) merupakan puncak tujuan dari proses pendidikan Islam, yakni membentuk murid menjadi manusia sempurna yang tugas dan fungsinya dijalankan dengan baik sebagai 'abid dan khalifah yang beriman dan beramal saleh.

Sumber nilai dalam Islam yang akan dipindahkan dalam pendidikan adalah al-Qur'an, al-Hadits, Qiyas, kemaslahatan umum, serta kesepakatan atau Ijma' dari ulama dan pemikir-pemikir Islam yang tentunya tidak boleh berlawanan dan harus selaras dengan isi dari al-Qur'an dan al-Hadits.

Sedangkan dalam kaitannya dengan penyusunan serta penerapan kurikulum pendidikan Islam, ada beberapa dasar yang harus dijadikan landasan, sebagaimana yang dijelaskan Langgulung berikut ini: (Langgulung, 2002: 28-30)

1) Keutuhan (syumuliyyah), yaitu aspek jasmani, jiwa, akal dan roh di dalam kurikulum pendidikan Islam harus bersifat utuh serta diberi perhatian secara menyeluruh sebagai individu ataupun anggota masyarakat.

2) Keterpaduan, yaitu komponen fisik, jiwa, roh dan akal harus dipandang sebagai satu kesatuan dalam kurikulum pendidikan Islam

3) Kesinambungan, yaitu bahwa ada keterkaitan antara kurikulum pendidikan Islam dan kelanjutan di setiap tahap usia, tingkatan pendidikan juga di setiap suasana.

4) Keaslian, artinya bahwa penyusunan kurikulum pendidikan Islam harus menggunakan komponen, materi ajar, tujuan pembelajaran, metode yang digunakan dari ajaran Islam itu sendiri.

5) Bersifat praktis, yakni penerapan dan seluruh isi kurikulum dititik beratkan agar murid menjadi muslim sesungguhnya yang memiliki iman dan taqwa dalam hidupnya. Juga bekerja dengan produktif sebagai pekerja serta pribadi masyarakat yang aktif.

Kemudian berdasarkan pengertian tersebut, Hasan Langgulung menjelaskan bahwa dalam kurikulum terdapat empat unsur yang utama, yaitu: 
1) Tujuan yang hendak dicapai berdasarkan kurikulum pendidikan.

2) Pengetahuan (knowledge) serta pengalaman yang terbentuk dalam kurikulum atau disebut dengan istilah mata pelajaran.

3) Metode atau cara mengajar yang digunakan oleh para guru dalam menyampaikan materi pelajaran.

4) Metode atau cara melakukan penelitian. Penelitian ini dimaksudkan untuk menilai dan mengukur kurikulum serta hasil dari pelaksanaan pendidikan yang direncanakan oleh kurikulum selama ini. (Langgulung, 2002:145)

Implikasi selanjutnya adalah Evaluasi. Evaluasi atau penilaian merupakan suatu hal yang mutlak dilakukan, karena dengan melakukan oenilaian evaluasi akan diketahui bahwa tujuan-tujuan pendidikan yang dirumuskan sudah dijalankan ataukah belum.

Langgulung berpendapat bahwa fungsi penilaian atau evaluasi dalam pendidikan Islam adalah:

1) Memilih orang-orang yang telah mencapai tujuannya di bidang pendidikan. Contohnya jika pendidikan bertujuan untuk bekerja, maka hanya mereka yang memiliki kemampuan bekerja yang diizinkan untuk memegang pekerjaan itu.

2) Sebagai alat peneguhan (reinforcement) bagi para pelajar. Peneguhan sendiri ialah imbalan dari pekerjaan yang telah dilakukannya. (Langgulung, 1986: 319)

\section{Kesimpulan}

Setelah dilakukan pembahasan dan analisa terhadap karya-karya Hasan Langgulung dan sumber-sumber lain yang mendukung, maka penulis menyimpulkan sebagai berikut:

1. Konsep asas psikologis dalam pendidikan Islam menurut Hasan Langgulung adalah dengan menekankan pada teori proses belajar serta konsep penciptaan manusia menurut pandangan Islam, yang meliputi hakikat penciptaan, potensi dasar manusia, pertumbuhan dan perkembangan kognitif serta psikologis dan ruhaniyah manusia, sehingga dapat dipahami bahwa manusia adalah mahluk yang terdiri dari unsur jasadiyah dan ruhaniyah.

2. Implikasi dari konsep asas psikologis dalam pendidikan Islam adalah memandang pendidikan sebagai proses untuk meyiapkan para generasi muda dalam mengisi perannya di masa yang akan datang, mentransfer ilmu pengetahuan dan nilai-nilai Islam yang disesuaikan dengan kedudukan manusia untuk beramal di dunia yang akan dipetik buahnya di akhirat. Oleh karena itu, dalam proses tersebut harus memperhatikan 
perkembangan fisik dan jiwa peserta didik dengan berbagai bahan, tujuan, dasar, kurikulum yang disertai dengan evaluasi yang membawa fungsi manusia sebagai 'abd dan khalifatullah fil 'ardl yang dihiasi dengan amal saleh.

\section{Daftar Rujukan}

Al Attas, Syed M. Nuquib. (2003). Filsafat dan Praktik Pendidikan Islam, ter. Wan Mohammad Nor Wan Daud. Bandung: Mizan.

Arifi, Ahmad. (1999). Politik Pendidikan Islam: Menelusuri Idiologi dan Aktualisasi Pendidikan Islam di Tengah Arus Globalisasi. Yogjakarta: Teras.

Assegaf, Abd. Rachman. (2004). Membangun Format Pendidikan Islam di Era Globalisasi., dalam Imam Machali dan Musthofa (Ed.). Pendidikan Islam dan Tantangan Globalisasi. Cet.I. Yogyakarta: Ar-Ruzz Media.

Azra, Azyumardi. (2000). Pendidikan Islam: Tradisi dan Modernisasi Menuju Milenium Baru.Cet.II. Jakarta: Logos Wacana Ilmu.

Bukhari, Imam. (1992). Shahih Bukhari, Kitabul Janaiz Bab Idza Aslama alShobiy Juz I. Beirut: Darul Kutubil Ilmiyah.

Daud, Wan Mohd. Nor Wan. (1998). The Educational Philosophy and Practice of Syed M.Naquib al-Attas, An Exposition of Original Concept of Islamization. Kuala Lumpur : ISTAC.

Furchan, Arief dan Maimun, Agus. (2005). Studi Tokoh, Metode Penelitian Mengenai Tokoh. Yogyakarta: Pustaka .

Hasan, M. Iqbal. (2002). Pokok-Pokok Materi Metodologi Penelitian Dan Aplikasinya. Jakarta: Ghalia Indonesia.

Kurniawan, Syamsul dan Mahrus, Erwin. (2011). Jejak Pemikiran Tokoh Pendidikan Islam. Jogyakarta: ar-Ruzz Media.

Langgulung, Hasan. (1980). Beberapa Pemikiran Tentang Pendidikan Islam. Bandung: al-Maarif.

Langgulung, Hasan. (1985). Pendidikan dan Peradaban Islam. Jakarta: Pustaka Al-Husna.

Langgulung, Hasan. (1986). Manusia dan Pendidikan: Suatu Analisa Psikologi dan Pendidikan. Jakarta: Pustaka Al-Husna.

Langgulung, Hasan. (1988). Asas- Asas Pendidikan Islam. Cet. ke-2. Jakarta: Al-Husna.

Langgulung, Hasan. (1991). Kreativitas dan Pendidikan Islam Analisis Psikologi dan Falsafah. Jakarta: Pustaka al-Husna.

Langgulung, Hasan. (2002). Peralihan Paradigma Dalam Pendidikan Islam dan Sains Sosial. Jakarta: Gaya Media Pratama. 
Mastuhu. (1999). Memberdayakan Sistem Pendidikan Islam. Jakarta: Logos.

Nata, Abuddin. (2003). Manajemen Pendidikan: Mengatasi Kelemahan Pendidikan di Indonesia. Bogor: Kencana.

Nata, Abuddin. (2008). Managemen Pendidikan: Mengatasi Kelemahan Pendidikan Islam di Indonesia. Cet. III. Jakarta: Kencana Prenada Media Group

Soejono, Abdurrahman. (1999). Metode Penelitian: Suatu Pemikiran dan Penerapannya. Jakarta: Rineka Cipta.

Surahmad, Winarno. (1990). Pengantar Penelitian Ilmiah: Dasar, Metode, Tehnik. Bandung: Tarsita.

Suyudi, M. (2005). Pendidikan Dalam Perspektif Al-Qur'an integrasi Epistemologi Bayani, Irfani, dan Burhani.Yogjakarta: Mikraj.

Syah, Muhibbin. (2007). Psikologi Belajar. Jakarta: Raja Grafindo Persada. 